\title{
Wilkes transform system and "nannoplate"
}

\author{
John A. Goff* Woods Hole Oceanographic Institution, Woods Hole, Massachusetts 02543 \\ Daniel J. Fornari* \\ James R. Cochran \\ Christopher Keeley \\ Alberto Malinverno \\ Lamont-Doherty Earth Observatory, Palisades, New York 10964
}

\begin{abstract}
A recent Hydrosweep survey of the Wilkes transform system, the second-fastest-slipping transform on the mid-ocean ridge system, shows it to be a highly complex and continually evolving plate boundary. An area $-50 \mathrm{~km}^{2}$ north of the eastern part of the Wilkes transform appears to be rotating counterclockwise in accordance with the theory of edge-driven microplate kinematics. We have called this region a "nannoplate" to distinguish it both as a separate small area of lithosphere between the Pacific and Nazca plates and as a smaller and less stable phenomenon than a microplate.
\end{abstract}

\section{INTRODUCTION}

The Wilkes transform system (Kureth and Rea, 1981; Lonsdale, 1989), located at approximately $9^{\circ} \mathrm{S}$ on the East Pacific Rise, contains the second fastest slipping (144 $\mathrm{mm} / \mathrm{yr}$ ) transform fault on the present-day mid-ocean ridge system (Demets et al., 1990). This transform fault system lies on a spreading-rate boundary between "normal" mid-ocean ridges, where conventional platetectonics wisdom of a rigid, ridge-transform geometry generally holds true, and a faster spreading regime, where the plate boundary is dominated by unstable phenomena such as propagating rifts, overlapping spreading centers, and microplates (Naar and Hey, 1989). In 1991 a multibeam bathymetric survey of the Wilkes transform complex was carried out using the Hydrosweep swathmapping system aboard the R/V Maurice Ewing (Cochran et al., 1993). Our analysis of the bathymetric and geophysical data shows the Wilkes to be a highly complex and continually evolving transform system, undergoing both a clockwise rotation in orientation and a stepwise southward migration over the past $3 \mathrm{~m} . \mathrm{y}$. In addition, we have identified an $-50 \mathrm{~km}^{2}$ region of discordant sea-floor morphology bounded to the east by the East Pacific Rise axis and to the west by a secondary rift basin that we infer to be an active pull-apart. Morphological evidence suggests that the secondary rift is quasi-stable and that the region of discordant seafloor structures is actively rotating counterclockwise in accordance with the theory of edge-driven microplate kinematics (Schouten et al., 1993). We call this region a "nannoplate" to distinguish it as moving in-

\footnotetext{
*Present addresses: Goff-University of Texas Institute for Geophysics, N. $8701 \mathrm{MoPac}$ Expressway, Austin, Texas 78759-8397; Fornari-Woods Hole Oceanographic Institution, Woods Hole, Massachusetts 02543.
}

dependently of the Pacific and Nazca plates and also to identify it as a smaller and less stable feature than known microplates.

\section{WILKES TRANSFORM SYSTEM}

The active Wilkes transform domain (Figs. 1 and 2) is $-100 \mathrm{~km}$ long and is contained between the W2 and W3 faults. It contains one intratransform spreading center (ITSC) (Fornari et al., 1989) 10 km long that is inferred to coincide with the sigmoidshaped basin just west of $109^{\circ} 00^{\prime} \mathrm{W}$ (Figs. 1 and 2). This feature is characterized by sea floor with high-amplitude Hydrosweep (C. Keeley, 1992, personal commun.) and SeaMARC II (K. Macdonald, 1993, personal commun.) sonar backscatter, inferred to represent bare rock or relatively young, unsedimented, or very thinly sedimented $(<1$ $\mathrm{m})$ volcanic terrain. The ancient fracturezone trace of the W3 scarp extends to the eastern limit of the survey area at an azimuth of $\mathrm{N} 99^{\circ} \mathrm{E}$, measurably different from the azimuth of $\sim \mathrm{N} 103^{\circ} \mathrm{E}$ of the active W3 fault trace. Kureth and Rea (1981) suggested that the W3 scarp may continue east to at least $104^{\circ} 48^{\prime} \mathrm{W}$, on the basis of a few widely spaced echo-sounder and magnetic survey lines.

An abandoned fracture-zone trace (W1) is present $\sim 20 \mathrm{~km}$ north of the W2 scarp. The W1 fault extends westward to the limit of the Hydrosweep survey area with a trend that appears to stabilize at $\sim \mathrm{N} 98^{\circ} \mathrm{E}$. The eastern end of the W1 scarp curves prominently southward until it intersects the W2 trace, which trends $\sim \mathrm{N} 106^{\circ} \mathrm{E}$, just east of the ITSC (Figs. 1 and 2). The W1 scarp is also present east of the eastern ridge-transform intersection as a curving lineament that truncates the southern terminus of abyssal-hill sea-floor fabric. The W1 transform fault was apparently cut off and abandoned when the East Pacific Rise axis propagated southward at $\sim 1.4-1.0 \mathrm{Ma}$. This time corresponds roughly to the onset of intratransform spreading in Wilkes, and the two events may be causally related.

South of the W3 scarp, in the area southwest of the ITSC, there exists a very complex left-lateral offset in the East Pacific Rise (Figs. 1 and 2). The continuity of abyssal-hill morphology both east and west of this offset implies that it represents a recent reorganization of the Wilkes transform system. Spreading east of the offset appears to be active in a series of deep basins. West of the offset, the axial high is well developed, but the rise crest loses its identity and is disrupted by crosscutting structures. On the basis of these observations, we suggest that the East Pacific Rise tip is retreating southward.

In addition to the W1-W3 scarps, a previously unidentified left-lateral fracture zone scarp, labeled W0 for consistency with Lonsdale's (1989) nomenclature, was discovered on both east and west transit lines (Fig. 3A). The W0 scarps, both trending at $\sim \mathrm{N} 97^{\circ} \mathrm{E}$, lie $\sim 45 \mathrm{~km}$ north of the presumed westward and eastward extension of the W1 scarp.

The Wilkes transform system appears to have recently undergone or to be currently undergoing a $4^{\circ}-9^{\circ}$ clockwise rotation in orientation. There are two lines of evidence to support this hypothesis. First, the ancient W0 and W1 scarps trend at $\sim \mathrm{N} 98^{\circ} \mathrm{E}$. The W0 fault was cut off prior to creation of the sea floor mapped within the survey area, and the W1 fault was cut off at approximately the same time that the $\sim \mathrm{N} 106^{\circ}$ E-trending W2 scarp was created. Second, the fracturezone traces of the W3 scarp trend at $\sim \mathrm{N} 99^{\circ} \mathrm{E}$, whereas the active W3 transform trends at $\sim \mathrm{N} 103^{\circ} \mathrm{E}$. In addition, there is considerable uncertainty as to the precise location of the ridge-transform intersection for the W3 transform between the ITSC and the western Wilkes ridge-transform intersection, where two adjacent scarps appear to be present (Fig. 2). This could indicate that the western part of the shear zone has very recently adjusted to a new plate geometry by forming an active fault at a new orientation. It is also possible that the recent reorientation of the W3 transform is causally related to the new offset in the accretionary plate boundary immediately to the south. 


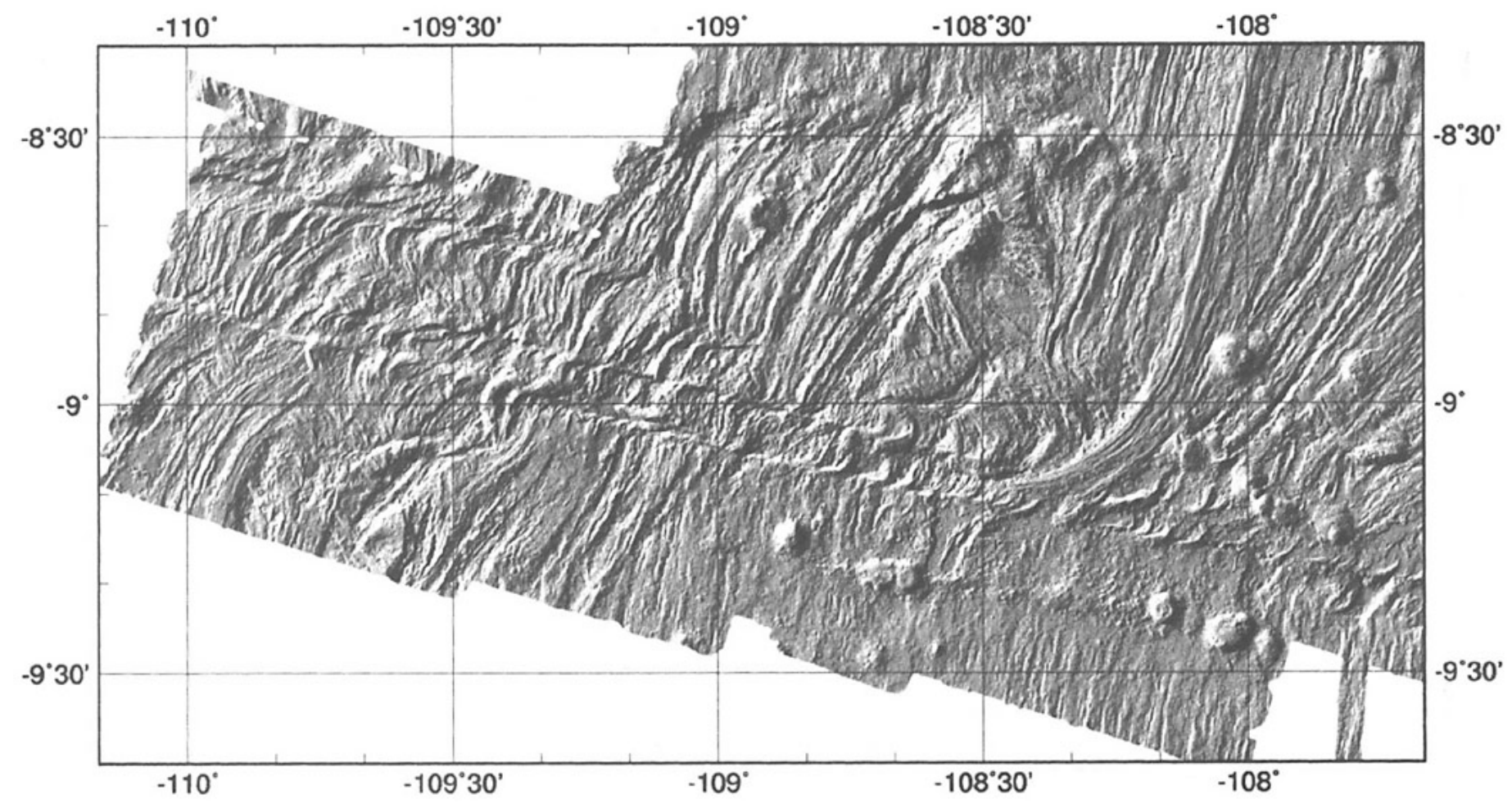

Figure 1. Shaded-relief image of Hydrosweep bathymetrlc data In vicinity of Wilkes transform system.

\section{WILKES NANNOPLATE}

A region of highly disrupted sea-floor morphology is located immediately north of the Wilkes transform between the ITSC and the eastern ridge-transform intersection. Inferred secondary off-axis rifting in this region has resulted in the creation of two deep rifts or pull-apart basins located about $50 \mathrm{~km}$ (centered on $\sim 108^{\circ} 35^{\prime} \mathrm{W}$ ) and $100 \mathrm{~km}$ (centered on $\sim 109^{\circ} 00^{\prime} \mathrm{W}$ ) west of the East Pacific Rise axis (Figs. 1 and 2). These rifts reach depths $\sim 1000-1500 \mathrm{~m}$ below the surrounding sea floor. Backscatter amplitude data (C. Keeley, 1992, personal commun.) show the $108^{\circ} 35^{\prime} \mathrm{W}$ rift to be highly reflective, indicating bare-rock or thinly sedimented sea floor; the backscatter amplitudes are equivalent to those at the volcanically active and young adjacent East Pacific Rise axis. The $108^{\circ} 35^{\prime} \mathrm{W}$ rift is $\sim 10 \mathrm{~km}$ east of an axis-parallel ridge that Lonsdale (1989) had identified as a possible overlapping spreading center. A prominent rifted ridge runs along the western margin of the $108^{\circ} 35^{\prime} \mathrm{W}$ rift basin and continues to the deepest part of the rift to the north (Figs. 1 and 2). This feature appears to cut across older abyssal hills and extends to the active W2 fault just east of the ITSC. We suggest that this feature may mark the site of organized, active accretion. The $109^{\circ} 00^{\prime} \mathrm{W}$ rift is much less reflective (C. Keeley, 1992, personal commun.), a qualitative indicator of the older age of this feature compared to the $108^{\circ} 35^{\prime} \mathrm{W}$ rift.

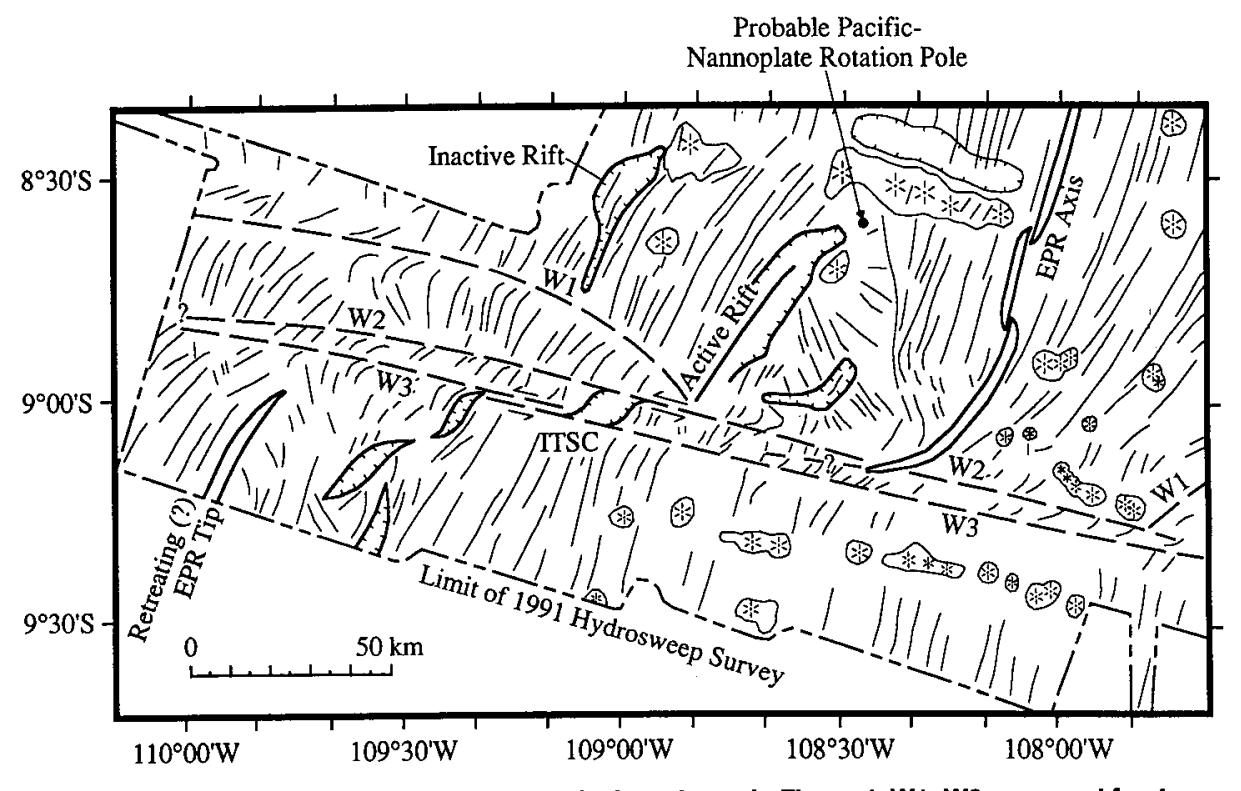

Figure 2. Structural interpretation of bathymetric data shown in Figure 1. W1-W3 represent fracturezone and transform-fault scarp traces. ITSC is Inferred intratransform spreading center. Asterisks represent seamount peaks. Wilkes nannoplate is reglon of highly disrupted sea floor bounded to east by East Pacific Rise axis, to west by $108^{\circ} 35^{\prime} \mathrm{W}$ rift, to south by W2 transform fault, and to north by $10-\mathrm{km}$-wide east-west ridge. Nomenclature of Lonsdale (1989) is used for scarps. Probable location of Pacific-nannoplate pole of rotation is also shown. Sense of nannoplate rotation is counterclockwise. Loci of possible Nazca-nannoplate poles of rotation lie on a line passing through this pole perpendicular to Pacific-Nazca relative motion.

Several crustal blocks with oblique abyssal-hill fabric are present between the $108^{\circ} 35^{\prime} \mathrm{W}$ rift and the East Pacific Rise axis, within a roughly triangular zone that extends to near the eastern ridge-transform intersec- tion (Figs. 1 and 2). At the northern boundary of the disrupted zone, a large $\sim 10$ $\mathrm{km}$-wide ridge, rising in some places to 1500 $\mathrm{m}$ above the surrounding sea floor, extends eastward from the northern end of the pre- 

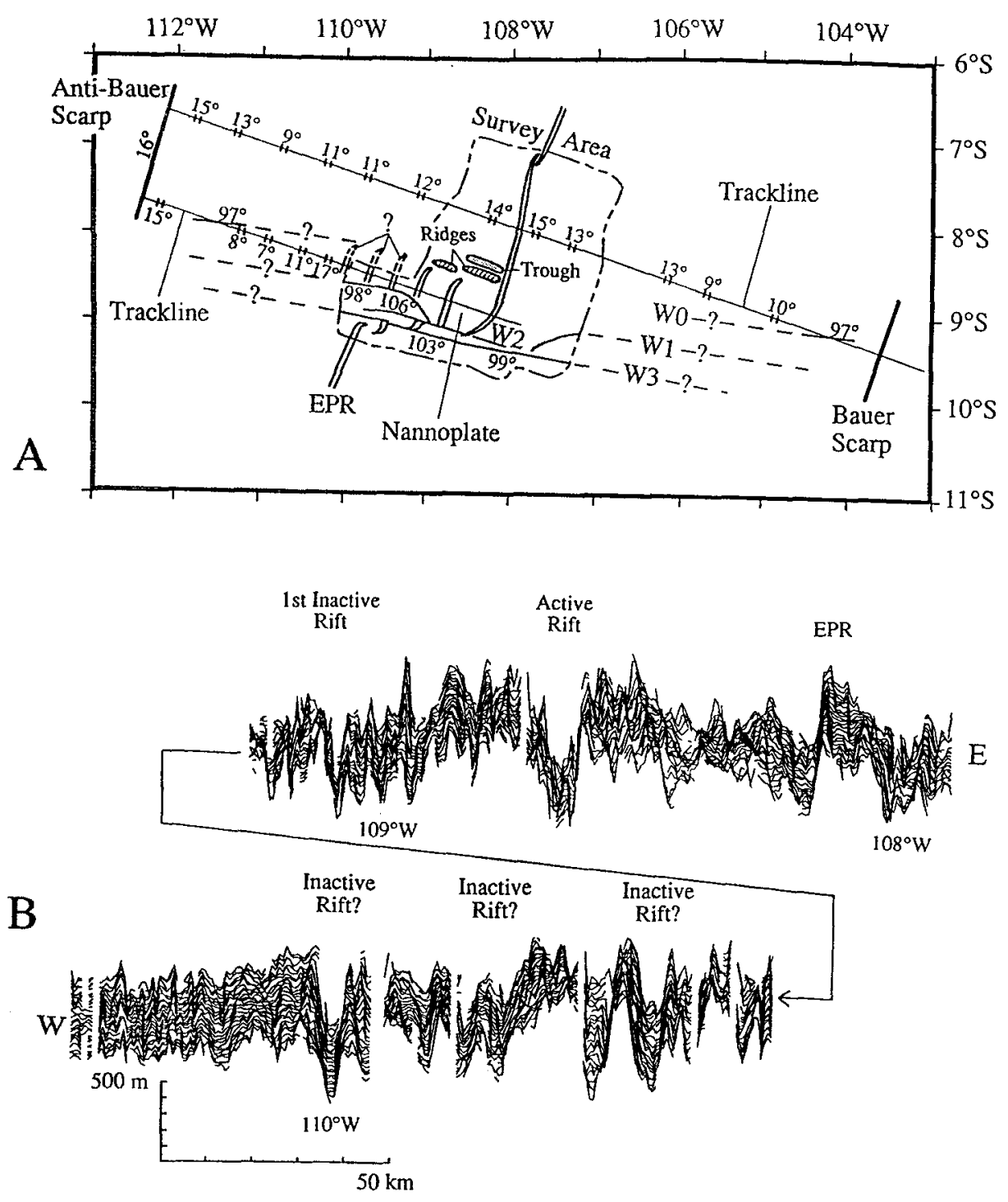

Flgure 3. A: Schematic representation of princlpal structures identified wlthin survey area (dotted line) and along two additional track lines extending from survey area to Bauer and Anti-Bauer scarps. Lineament azimuths are given in degrees east from north. Double hachures along track lines indicate measurement of abyssal-hill lineaments. W0-W3 represent fracture-zone and transform-fault scarp traces. Long-dash lines represent assumed scarp locations based on extrapolation of observed trends. B: Continuous swath of Hydrosweep data along southern track line shown in A. From west to east, track line passes over East Pacific Rise crest, Wilkes nannoplate, complex region to west of nannoplate, and sudden transition to normal-looking abyssal-hill morphology.

sumed active $108^{\circ} 35^{\prime} \mathrm{W}$ rift to the East Pacific Rise axis. Immediately north of this ridge there is a shallow bathymetric trough (Figs. 1 and 2). A similar ridge, although not as large, extends eastward from the northern tip of the inactive $109^{\circ} 00^{\prime} \mathrm{W}$ rift.

Two lines of evidence suggest that the region between the East Pacific Rise axis and the inferred active $108^{\circ} 35^{\prime} \mathrm{W}$ rift is rotating in response to edge-driven microplate-style tectonics (Schouten et al., 1993). The first is the similarity of secondary rift morphology to that observed at the Pito Deep of the Easter microplate (e.g., Naar and Hey, 1991) and the Endeavor Deep of the Juan Fernandez microplate (e.g., Larson et al., 1992). In
Hey, 1991) and Juan Fernandez (e.g., Larson et al., 1992) microplates immediately adjacent to their respective deeps. These features have been interpreted as resulting from compressional stresses induced by the forced rotation of the microplate.

The region lying between the East Pacific Rise axis and the $108^{\circ} 35^{\prime} \mathrm{W}$ rift is therefore identified as piece of lithosphere detached and moving independently from either the Pacific or Nazca plate. Thus it merits a "plate" identification. We call this region the Wilkes "nannoplate," which implies similarity to known microplates but identifies it as a smaller and a less stable phenomenon. The Wilkes nannoplate is very similar in size and gross morphology to the Orozco "picoplate" (Macdonald et al., 1992). (We prefer the prefix "nanno" as it implies one rather than two orders in size difference with "micro") located $\sim 15^{\circ} 30^{\prime} \mathrm{N}$ on the East Pacific Rise system.

The Pacific-nannoplate pole of rotation appears to be located at the northwest corner of the nannoplate, where we see evidence for a rapid transition from extension along the western edge to compression along the northern edge (Fig. 2). The nannoplate rotation is counterclockwise, opposite to the rotations of the Easter and Juan Fernandez microplates. The model of Schouten et al. (1993) implies that the Nazca-nannoplate pole of rotation is located at the intersection of the southern nannoplate boundary and a line perpendicular to Nazca-Pacific plate motion and passing through the Nazca-nannoplate rotation pole. If this pole were located right on the nannoplate boundary, we would expect the East Pacific Rise to have a nearly zero spreading rate as it approaches the ridge-transform intersection. However, though there is significant curvature, the East Pacific Rise maintains an axial high to the intersection, a probable indication of fast spreading throughout. If this is true, then the Nazca-nannoplate pole is located some distance south of the actual microplate edge.

Constraints on this rotation system are marginal at best. Nevertheless, we anticipate a component of compression or dilatation along parts of the southern nannoplate boundary with the W2 fault. Also unconstrained is the extent to which the nannoplate is behaving rigidly or is being deformed. It is likely that many of the morphological complexities of the nannoplate interior are best explained by distributed deformation and internal shearing.

In addition to the ridge crest and flank survey (Cochran et al., 1993), bathymetric data were collected along a transit into the survey area from the east and along two track lines that extended to the Anti-Bauer scarp (on 

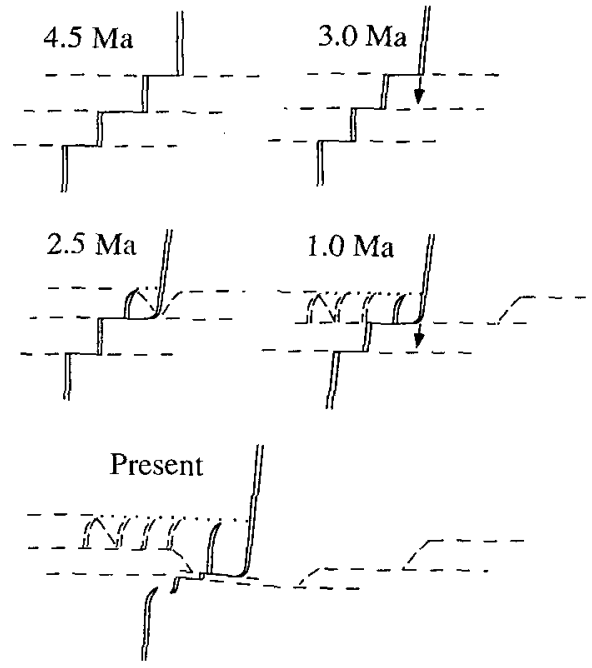

Figure 4. Illustration of our working hypothesis for evolution of Wilkes transform system and nannoplate. At $\sim 4.5 \mathrm{Ma}$, system exists as three distinct transform faults. At $\sim 3.0 \mathrm{Ma}$, northern segments undergo clockwise rotation, Initiating southward propagation of Wo transform. At $\sim 2.5 \mathrm{Ma}$, propagation of WO transform is complete, but western rift fails to shut off, initiating overfappling spreading. At $\sim 1.0 \mathrm{Ma}$, several rifts have formed and been abandoned as new rifting begins inward of old location (perhaps in response to rotation of asymmetric overlap region). Southern segments now rotate clockwise; in response, W1 transform propagates southward into newly formed W2 transform. Near present, W3 transform also undergoes clockwise reorientation, perhaps initiating formation of new ridge offset to south. Dots represent trace of Paclfic-nannoplate compressive boundary.

-6 Ma crust) to the west (Fig. 3A). One of the western track lines enters the survey area at the location of the nannoplate (Fig. 3B). Along this track line, highly rotated morphology with three additional deep $(500-700 \mathrm{~m})$, north-trending valleys exists out to $\sim 220 \mathrm{~km}(-3 \mathrm{Ma}$ crust) west of the East Pacific Rise axis. Although our coverage of this region is minimal, this complex morphology could represent prior episodes of secondary rifting. We thus tentatively identify the deep valleys seen in Figure 3B as additional inactive rifts. Abyssal hills just west of $110^{\circ} \mathrm{W}$ appear typical of a fastspreading mid-ocean ridge flank. However, their trends indicate that a change in orientation of $\sim 6^{\circ}$ preceded the onset of complex rift-ridge morphology (Fig. 3B).

The identification of several additional possible inactive rifts and complex, rotated morphology west of the inferred active rift at $108^{\circ} 35^{\prime} \mathrm{W}$ suggests that the nannoplate is a quasi-steady-state phenomenon that began forming at $\sim 3.0 \mathrm{Ma}$. The $109^{\circ} 00^{\prime} \mathrm{W}$ rift, with a morphology very similar to that of the active $108^{\circ} 35^{\prime} \mathrm{W}$ rift, is the clearest evidence that prior rifting has occurred but that the site of rifting has migrated spatially.

In our hypothesis for the history of the Wilkes nannoplate (Fig. 4), the beginning of the nannoplate is very obscure, but it is possible that a small rotation in local spreading direction at $\sim 3.5 \mathrm{Ma}$ (indicated by the variation in abyssal-hill trends shown in Fig. 3A) was responsible for secondary rifting to the west of the East Pacific Rise axis. A suggested mechanism for initiating overlapping spreading is for the rise axis to propagate southward past the W0 scarp to the W1 scarp while failing to shut off the supposed "doomed" axis (Fig. 4). This possibility is consistent with the inferred history of the more recently initiated Orozco "picoplate" (Madsen et al., 1986; Macdonald et al., 1992). However, the kinematics of the Wilkes double-rift system clearly require some instability, given the very fast spreading rise axis to the east, possible amagmatic or slowly spreading rift to the west, and fairly stable (through time) northern and southern boundaries. As time progresses, the site of secondary rifting will move westward very rapidly. The nannoplate will then take on a more rectangular shape, becoming very long in the east-west direction. Though the nannoplate will still be subject to edgedriven forces, its rectangular shape will strongly resist rotation. To allow rotation, a new rift must develop eastward of the old one to maintain a roughly circular nannoplate shape. We suggest that this process has been repeated approximately four times since the initial rifting event at $3.0 \mathrm{Ma}$. The southward propagation of the East Pacific Rise past the W1 scarp at $\sim 1.2 \mathrm{Ma}$ has enlarged the nannoplate, suggesting that the nannoplate is gaining stability through growth and may develop into a fully rigid microplate.

\section{SUMMARY AND CONCLUSIONS}

The morphology of the Wilkes transform and fracture zone reveals a history of stepwise southward migration of a complex system of left-lateral transform offsets. The evolution of this system appears to have been driven by a $4^{\circ}-9^{\circ}$ clockwise rotation in the relative motion between the Nazca and $\mathrm{Pa}$ cific plates over the past 3-4 m.y. Secondary rifting west of the East Pacific Rise in the wake of southward migration has formed a $50 \mathrm{~km}^{2}$ area we call a "nannoplate" that is rotating counterclockwise independently of either the Nazca or Pacific plate. Secondary rifting appears to be quasi-stable, persisting for $3 \mathrm{~m} . \mathrm{y}$. but migrating spatially, perhaps to accommodate rotational stresses. Recent enlargement of the nannoplate suggests that it is gaining stability and may evolve into a microplate.

\section{ACKNOWLEDGMENTS}

Supported by National Science Foundation grants OCE-9019741 (Woods Hole Oceanographic Institution) and OCE-8911376 (LamontDoherty Earth Observatory). We are greatly indebted to Martin Kleinrock, Deborah Smith, and Ken Macdonald for helpful comments and stimulating discussion and to Roger Larson and an anonymous reviewer for insightful reviews. WHOI contribution 8221. LDGO contribution 5043 .

\section{REFERENCES CITED}

Cochran, J.R., Goff, J.A., Malinverno, A., Fornari, D.J., Keeley, C., and Wang, X., 1993, Morphology of a "superfast" mid-ocean ridge crest and flanks: The East Pacific Rise, $7^{\circ}-9^{\circ} \mathrm{S}$ : Marine Geophysical Research (in press).

Demets, C., Gordon, R.G., Argus, D.G., and Stein, S., 1990, Current plate motions: Geophysical Journal, v. 101, p. 425-478.

Fornari, D.J., Gallo, D.G., Edwards, M.H., Madsen, J.A., Perfit, M.R., and Shor, A.N., 1989, Structure and topography of the Siqueiros transform fault system: Evidence for the development of intra-transform spreading centers: Marine Geophysical Research, v. 11, p. 263-299.

Kureth, C.L., and Rea, D.K., 1981, Large-scale oblique features in an active transform fault, the Wilkes fracture zone near $9^{\circ} S$ on the East Pacific Rise: Marine Geophysical Research, v. 5, p. 119-137.

Larson, R.L., and 8 others, 1992, Roller-bearing tectonic evolution of the Juan Fernandez microplate: Nature, v. 356, p. 571-576.

Lonsdale, P., 1989, Segmentation of the PacificNazca spreading center, $1^{\circ} \mathrm{N}-20^{\circ} \mathrm{S}$ : Journal of Geophysical Research, v. 116, p. $12,197-12,225$.

Macdonald, K.C., and 12 others, 1992, The East Pacific Rise and its flanks 8-18 N: History of segmentation, propagation and spreading direction based on SeaMARC II and Sea Beam studies: Marine Geophysical Research, v. 14, p. 299-344.

Madsen, J.A., Fox, P.J., and Macdonald, K.C., 1986, Morphotectonic fabric of the Orozco transform fault: Results from a Sea Beam investigation: Journal of Geophysical Research, v. 91, p. 3439-3454.

Naar, D.F., and Hey, R.N., 1989, Speed limit for oceanic transform faults: Geology, v. 17, p. 420-422.

Naar, D.F., and Hey, R.N., 1991, Tectonic evolution of the Easter microplate: Journal of Geophysical Research, v. 96, p. 7961-7993.

Schouten, H., Klitgord, K.D., and Gallo, D.G., 1993, Edge-driven microplate kinematics: Journal of Geophysical Research (in press).

Manuscript received November 19, 1992

Revised manuscript received February 18, 1993 Manuscript accepted March 1, 1993 